\title{
Heritability of Fresh-cut Fruit Quality Attributes in Capsicum
}

\author{
John R. Stommel ${ }^{1}$ \\ Genetic Improvement of Fruits and Vegetables Laboratory, U.S. Department of Agriculture, \\ Agricultural Research Service, Beltsville Agricultural Research Center, Beltsville, MD 20705-2325
}

Mary J. Camp

Biometrical Consulting Service, U.S. Department of Agriculture, Agricultural Research Service, Beltsville Agricultural Research Center, Beltsville, MD 20705-2325

Judith M. Dumm and Kathleen G. Haynes

Genetic Improvement of Fruits and Vegetables Laboratory, U.S. Department of Agriculture, Agricultural Research Service, Beltsville Agricultural Research Center, Beltsville, MD 20705-2325

Yaguang Luo

Food Quality Laboratory, U.S. Department of Agriculture, Agricultural Research Service, Beltsville Agricultural Research Center, Beltsville, MD 20705-2325

\author{
Anne Marie Schoevaars \\ Enza Zaden Research USA, Inc., 525 Lucy Brown Lane, San Juan Bautista, CA 95045-9533
}

AdDitional INDEX words. electrolyte leakage, heritability, germplasm, modified atmosphere packaging, pepper, shelf life

\begin{abstract}
Fresh pepper (Capsicum) fruit that are sliced and/or diced are referred to as fresh-cut products. The current report evaluates the inheritance of postharvest attributes that contribute to pepper fresh-cut quality. Marketable green fruit of large-fruited Capsicum annuum accessions with bell and related pod types (Class 1), $C$. annuum accessions with jalapeno and serrano pod types (Class 2), and thin-walled "aji"-like tabasco pod types from Capsicum baccatum, Capsicum frutescens, and Capsicum chinense (Class 3) were processed and stored up to 14 days in selective oxygen transmission rate packaging. Fresh-cut attributes were influenced by genotype as well as year. For all pod types, $\mathrm{O}_{2}$ and $\mathrm{CO}_{2}$ partial pressures in storage packages, tissue weight loss, and electrolyte leakage differed among accessions, days of storage, and years of testing. Percent $\mathrm{O}_{2}$ declined and $\mathrm{CO}_{2}$ and electrolyte leakage generally increased during storage. Some accessions in Class 1 and Class 2 maintained acceptable product quality during storage. Changes in fruit weight loss were small with greater weight loss observed in Class 1 accessions relative to weight loss for Class 2 and Class 3. Broad-sense heritability for fresh-cut attributes was moderate to low indicating that it will be difficult to breed for fresh-cut quality.
\end{abstract}

Fresh pepper fruit that are sliced and/or diced are referred to as fresh-cut products. Pepper and other minimally processed fresh-cut vegetables have been used primarily in food service sales and to a lesser extent in retail markets (Lamikanra, 2002). Tissue breakdown and microbial contamination are important problems that shorten product shelf life of pepper and other fresh-cut fruits and vegetables (Barrett et al., 2010). Numerous factors contribute to fresh-cut product shelf life. Preharvest factors that affect raw material and resultant processed product quality include genotypic differences, climatic factors, and cultural practices (Kader, 2002). Multiple postharvest factors also influence fresh-cut product quality (James and Ngarmask, 2010). Physical damage during harvesting and handling, temperature and relative humidity management of harvested product, and supplemental postharvest treatments including modified atmospheres (MAs) can positively or negatively affect the quality of fresh-cut products.

Received for publication 17 Nov. 2015. Accepted for publication 5 Apr. 2016. Mention of trade names or commercial products is solely for the purpose of providing specific information and does not imply recommendation or endorsement by the United States Department of Agriculture.

${ }^{1}$ Corresponding author. E-mail: john.stommel@ars.usda.gov.
Steps involved in production of fresh-cut pepper products include precooling and washing of freshly harvested fruit followed by trimming, coring, slicing, packaging, and storage at $4{ }^{\circ} \mathrm{C}$. Electrolyte leakage is commonly used as a measure of cell disruption that occurs during cutting of fresh-cut product and tissue breakdown during storage (Allende et al., 2004; Kim et al., 2004; Luo et al., 2004). Tissue softening and progression of fruit ripening that continues after processing, texture loss, desiccation, and decay due to tissue damage and microbial contamination shorten shelf life of fresh-cut product. A number of studies have evaluated pepper for fresh-cut use and focused on fresh-cut product storage temperature and controlled atmosphere storage (Cantwell and Suslow, 2002; Conesa et al., 2007; Gonzalez-Aguilar et al., 2004; Lopez-Galvez et al., 1997; Manolopoulou et al., 2012; Senesi et al., 2000). Low $\mathrm{O}_{2}$ and high $\mathrm{CO}_{2}$ concentrations reduce respiration rates and ethylene production. Although pepper is susceptible to chilling injury (CI), potential damage due to $\mathrm{CI}$ is offset by the beneficial effects of cold storage on retarding tissue decay. These studies evaluated only one to several cultivars from the sweet bell market class. Howard and Hernandez-Brenes (1998) assessed the suitability of a single jalapeno pepper cultivar for fresh-cut applications. Where more than one cultivar was evaluated, 
longevity of the fresh-cut product was influenced by choice of cultivar and limited by tissue breakdown and/or microbial decay. Stommel et al. (2015) evaluated diverse Capsicum germplasm representative of various fruit pod types for freshcut suitability. Sweet bell and other large-fruited pod types and jalapeno and serrano accessions varied extensively in suitability for fresh-cut use with some accessions identified within each class that maintained acceptable sensory quality and tissue integrity during storage.

Extensive genetic diversity in Capsicum has been characterized (Stommel and Albrecht, 2012). Breeding for tolerance to biotic and abiotic disorders in cultivated pepper has largely focused on improving fruit quality, disease resistance, and varied yield attributes. Genetic diversity, varied production practices, and different maturity stages of harvested product present difficulties in establishing standard selection practices to breed for postharvest quality (Hayes and Luo, 2008). Detailed reports on breeding for postharvest attributes are few. This may be attributed to the expertise and resources often required to conduct postharvest assessment of quality attributes. The current report evaluates the heritability of postharvest attributes that contribute to fresh-cut product quality in diverse pepper pod types.

\section{Materials and Methods}

Plant materials. Pepper cultivars and Capsicum species accessions were selected to represent a range of fresh-cut quality ranging from good to poor (Stommel et al., 2015). Pepper seed of selected accessions was obtained from Enza Zaden (lines denoted with E or caps prefix); Plant Genetic Resources Conservation Unit, U.S. Department of Agriculture, Agricultural Research Service, Griffin, GA (PI441548); and commercial suppliers (named cultivars). Three 12-plant replicates of 6-week-old plants of each accession were transplanted following a randomized complete block design to field plots at the Beltsville Agricultural Research Center, Beltsville, MD, during the 2013 and 2014 summer production seasons. Field-grown plants were spaced at $0.45-\mathrm{m}$ intervals in single rows on polyethylene-covered raised beds positioned on $1.5-\mathrm{m}$ centers with trickle irrigation. Pest control and fertilizer regimes followed standard practices for pepper production in Maryland (University of Maryland, 2016).

The accessions evaluated represented various pepper fruit pod types. Class 1 was composed of 20 large-fruited C. annuum accessions with bell, paprika, pimento, and large elongated pod types. Sixteen small-fruited $C$. annuum accessions with jalapeno and serrano pod types plus small-fruited cherry pod types comprised Class 2 . Class 3 included seven C. baccatum, C. frutescens, and C. chinense accessions with thin-walled "aji"-like and tabasco pod types. Market maturity for full-size green fruit for respective accessions was assessed via subjective evaluation of fruit color and firmness during development, and marketable green fruit was harvested. Three replicate fruit samples of each accession were obtained by harvest from three groups of four plants each from respective 12 plant replicates and stored at $7{ }^{\circ} \mathrm{C}$ overnight before processing.

Fruit Processing. Pepper fruit were processed as previously described (Stommel et al., 2015). Fruit were washed for $1 \mathrm{~min}$ in chlorinated water containing $50 \mathrm{mg} \cdot \mathrm{L}^{-1}$ free sodium hypochlorite $(\mathrm{NaOCl})$ adjusted to $\mathrm{pH} 6.0$ to 7.0. Deseeded fruit were sliced transversely in 0.6-cm-thick rings using an industrial slicer (Emura Digisler ECD-302; Emura Food Machine Co., Nagoya, Japan) and washed in $50 \mathrm{mg} \cdot \mathrm{L}^{-1} \mathrm{NaOCl}$ in water for $0.5 \mathrm{~min}$. Washed fruit slices were centrifuged in a fresh produce centrifuge (Garroutte, Watsonville, CA) for $2 \mathrm{~min}$ at $20.5 \mathrm{~g}_{\mathrm{n}}$, and $50.0 \pm 1.0 \mathrm{~g}$ samples of sliced pepper for evaluation at 0,7 , and $14 \mathrm{~d}$, respectively, for each replicate were transferred to $19 \times 28 \mathrm{~cm}$ heat-sealed polypropylene bags (CFS Cellpack Packaging, Illfurth, France) with an oxygen transmission rate of $1193 \mathrm{~mL} \cdot \mathrm{m}^{-2} \mathrm{O}_{2}$ per $24 \mathrm{~h}$. Samples were stored in the dark at 5 to $7^{\circ} \mathrm{C}$ before evaluation (Barth et al., 2016).

Fresh-Cut evaluation. Packaged fruit slices were removed from cold storage after 7 - and 14-d equivalent test periods for both years and percent $\mathrm{O}_{2}$ and $\mathrm{CO}_{2}$ measured in the headspace of sealed bags using a gas analyzer (CheckMate II; PBI Dansensor, Ringsted, Denmark). Weight of the samples in each package was recorded and electrolyte leakage was determined as described by Hong et al. (2000) and Kou et al. (2013) with minor modifications (Stommel et al., 2015). Fruit slices were transferred to $500 \mathrm{~mL}$ reverse osmosis (RO) quality water, incubated for $30 \mathrm{~min}$ and electrical conductivity $\left(\mathrm{EC}_{1}\right)$ was measured. Samples in $\mathrm{RO}$ water were frozen slowly to $-20{ }^{\circ} \mathrm{C}$ for 24 to $48 \mathrm{~h}$ to maximize tissue disruption, thawed, and total product $\mathrm{EC}$ was recorded $\left(\mathrm{EC}_{2}\right)$ over repeat freeze-thaw cycles until total $\mathrm{EC}$ was stable. Percent electrolyte leakage was calculated as $\left.\left(\mathrm{EC}_{1}-\mathrm{EC}_{0}\right) / \mathrm{EC}_{2}-\mathrm{EC}_{0}\right) \times 100$, where $\mathrm{EC}_{0}=\mathrm{EC}$ of $\mathrm{RO}$ water.

Statistical analysis. The variables $\mathrm{O}_{2}, \mathrm{CO}_{2}$, weight change, and electrolyte leakage were analyzed as two-factor mixed models using Proc Mixed in SAS (version 12.1; SAS Institute, Cary, NC) with accession and day as the factors and year as the block. For electrolyte leakage, measurements were recorded at $0 \mathrm{~d}$ as well as at 7 and $14 \mathrm{~d}$. The assumptions of the models were checked. For Class 2, electrolyte leakage was log transformed to meet the assumptions of the linear model. Values that showed as probable outliers were reviewed in the master data set and omitted from the analyses. The variance grouping technique was used to correct variance heterogeneity present in all three pepper classes. Means comparisons were done with Sidak adjusted probability values so that the experiment-wise error was 0.05 .

Variance components estimated from the mixed models procedure were used to calculate broad-sense heritability as

$$
H=\frac{\sigma_{\mathrm{G}}^{2}}{\sigma_{\mathrm{G}}^{2}+\left(\sigma_{\mathrm{GE}}^{2} / \mathrm{e}\right)+\left(\sigma_{\mathrm{e}}^{2} / \mathrm{re}\right)}
$$

where $\sigma_{G}^{2}$ is the genetic variance, $\sigma^{2}$ GE the genotype $\times$ environment variance, $\sigma_{\mathrm{e}}^{2}$ the error variance, and re the total number of fruit replicates analyzed per accession. The data were also analyzed by the SAS general linear models procedure, and type III mean squares were used to calculate the upper and lower confidence interval of the estimate of $H$ (Knapp et al., 1985) as

$$
\begin{aligned}
& \text { Upper CI }=1-\left[1 /\left\{\left(\mathrm{MS}_{1} / \mathrm{MS}_{2}\right) \mathrm{F}_{(1-\alpha / 2 ; \mathrm{df} 2, \mathrm{df1})}\right\}\right] \\
& \text { Lower CI }=1-\left[1 /\left\{\left(\mathrm{MS}_{1} / \mathrm{MS}_{2}\right) \mathrm{F}_{(\alpha / 2 ; \mathrm{df} 2, \mathrm{df1})}\right\}\right]
\end{aligned}
$$

where $\mathrm{MS}_{1}=$ mean squares for accession, $\mathrm{MS}_{2}=$ mean squares for accession $\times$ year, $F=F$-distribution value, $\alpha=0.05, \mathrm{df} 2=\mathrm{df}$ 
associated with accession $\times$ year, and $\mathrm{df} 1=\mathrm{df}$ associated with accession.

\section{Results}

Attributes that contribute to fresh-cut pepper fruit quality were influenced by genotype as well as environment. For accessions comprising Class 1, Class 2, and Class 3, fresh-cut parameters including $\mathrm{O}_{2}$ and $\mathrm{CO}_{2}$ partial pressures in storage packages, tissue weight loss, and electrolyte leakage generally differed significantly among accessions and between days of storage as well as between years of testing (Table 1). With the exception of tissue weight loss in Class 1 , accession $\times$ day interactions were significant in Class 1 and Class 2, but not in Class 3. Year of testing generally had a large effect on these fresh-cut parameters for all fruit classes. For Class 1 and Class 2, days of storage also had a strong influence on percent $\mathrm{O}_{2}$ and $\mathrm{CO}_{2}$, weight loss, and electrolyte leakage. For Class 3 , accessions had greater influence on percent $\mathrm{CO}_{2}$ and weight loss relative to days of storage, whereas days of storage had greater effects on percent $\mathrm{O}_{2}$.

An inverse relationship was evident between percent $\mathrm{O}_{2}$ and $\mathrm{CO}_{2}$ in sample storage bags with percent $\mathrm{O}_{2}$ generally declining and $\mathrm{CO}_{2}$ increasing over days of storage (Table 2). Percent $\mathrm{O}_{2}$ declined faster in Class 2 and Class 3 samples after 7 and $14 \mathrm{~d}$ of storage relative to that observed for Class 1 . Whereas $\approx 35 \%$ of the accessions represented within Class 1 maintained both $\mathrm{O}_{2}$ and $\mathrm{CO}_{2}$ partial pressures within recommended ranges for fresh-cut pepper $\left[3 \%\right.$ to $5 \% \mathrm{O}_{2}, 5 \%$ to $10 \% \mathrm{CO}_{2}$ (Barth et al., 2016)], only $12.5 \%$ of Class 2 small-fruited C. annuum accessions maintained optimal package MAs. These included the cherry accession caps5951 and a jalapeno accession 'Goliath'. Percent $\mathrm{O}_{2}$ was depleted to low levels in the remaining Class 2 samples after $14 \mathrm{~d}$ of storage. Overall, percent $\mathrm{O}_{2}$ declined to suboptimal levels in most Class 3 C. chinense, $C$. frutescens, and $C$. baccatum accessions as well after $14 \mathrm{~d}$ of storage.

Table 1. Analysis of variance $\mathrm{F}$ values for $\mathrm{O}_{2}, \mathrm{CO}_{2}$, weight loss, and electrolyte leakage of fresh-cut pepper slices from large-fruited Capsicum annuum accessions with bell, paprika, pimento, and large elongated pod types (Class 1); small-fruited C. annuum accessions with jalapeno, serrano, and cherry pod types (Class 2); and accessions of Capsicum baccatum, Capsicum frutescens, and Capsicum chinense with thin-walled "aji"-like and tabasco pod types (Class 3) stored under passive modified atmosphere packaging conditions for 7 to $14 \mathrm{~d}$.

\begin{tabular}{|c|c|c|c|c|c|c|}
\hline \multirow[b]{2}{*}{ Source } & \multirow[b]{2}{*}{ df } & $\mathrm{O}_{2}$ & $\mathrm{CO}_{2}$ & Wt loss & \multirow[b]{2}{*}{$\mathrm{df}$} & \multirow{2}{*}{$\frac{\text { Electrolyte leakage }}{\mathrm{F} \text { value }}$} \\
\hline & & & F value & & & \\
\hline \multicolumn{7}{|l|}{ Class 1} \\
\hline Year & 1 & $257.37 * * * *$ & $17.58 * * * *$ & $39.01 * * * *$ & 1 & $92.27 * * * *$ \\
\hline Accession & 19 & $3.22 * * * *$ & $3.16^{* * * *}$ & $3.38 * * * *$ & 19 & $6.68 * * * *$ \\
\hline Day & 1 & $194.38 * * * *$ & $102.97 * * * *$ & $31.72 * * * *$ & 2 & $52.46 * * * *$ \\
\hline Accession $\times$ day & 19 & $1.67 * * * *$ & $1.98 *$ & 1.48 & 38 & $4.47 * * * *$ \\
\hline \multicolumn{7}{|l|}{ Class 2} \\
\hline Year & 1 & $37.26^{* * * *}$ & $7.37 * *$ & 0.85 & 1 & $163.66 * * * *$ \\
\hline Accession & 15 & $4.04 * * * *$ & $6.89 * * * *$ & $5.22 * * * *$ & 15 & $82.54 * * * *$ \\
\hline Day & 1 & $54.97 * * * *$ & $16.37 * * * *$ & $39.32 * * * *$ & 2 & $66.76^{* * * *}$ \\
\hline Accession $\times$ day & 15 & $2.24 * *$ & $2.12 *$ & $2.76^{* *}$ & 30 & $10.99 * * * *$ \\
\hline \multicolumn{7}{|l|}{ Class 3} \\
\hline Year & 1 & $26.51 * * * *$ & 0.01 & $64.10 * * * *$ & 1 & $15.59 * * *$ \\
\hline Accession & 6 & $2.28 *$ & $3.34 * *$ & $11.13 * * * *$ & 6 & $23.54 * * * *$ \\
\hline Day & 1 & $23.45 * * * *$ & 0.75 & $15.49 * * *$ & 2 & $15.40 * * * *$ \\
\hline Accession $\times$ day & 6 & 1.42 & 2.09 & 0.98 & 12 & 1.76 \\
\hline
\end{tabular}

Electrolyte leakage after $14 \mathrm{~d}$ of storage for Class 1 accessions was variable. Although electrolyte leakage values increased for many of the accessions, values were relatively unchanged over the evaluation period for accessions including 'Inzell', E20B.24966, E49.10719, 'Healey', and 'Holy Mole'. Electrolyte leakage declined significantly in 'Planet' over days of storage. For Class 2 and Class 3, changes in electrolyte leakage over the $14 \mathrm{~d}$ storage period were less varied in comparison with Class 1 accessions and were generally typified by smaller increases in accessions where electrolyte leakage increased during storage. Similar to Class 1, electrolyte leakage was relatively unchanged (e.g., 'Cherry Bomb', and 'Jalapeno') or declined during storage (e.g., 'Mitla', 'Goliath', and 'Ixtapa $\mathrm{X} 3 \mathrm{R}$ ') for select accessions. In Class 2, one jalapeno accession ('Ixtapa X3R') and all five serrano accessions exhibited electrolyte leakage values at day 0 that were greater than that observed in other Class 1 and Class 2 samples, suggesting that greater tissue damage occurred in these accessions during sampling.

Overall, changes in fruit weight loss were small with greater weight loss in Class 1 accessions after $14 \mathrm{~d}$ of storage relative to weight loss observed for Class 2 and Class 3 accessions. Two large-fruited $C$. annuum accessions, 'Pimiento Elite' and 'Alma Paprika', exhibited the greatest weight loss after $14 \mathrm{~d}$ of storage, coincident with the greatest electrolyte leakage in this fruit class.

Broad-sense heritability estimated for fresh-cut attributes after $14 \mathrm{~d}$ of storage varied from high to low depending on the attribute and fruit class (Table 3 ). Considerable variation with fresh-cut quality measures reduced the precision of heritability estimates, particularly for $\mathrm{O}_{2}$ and $\mathrm{CO}_{2}$ partial pressures and tissue weight loss. Higher heritability estimates were evident for electrolyte leakage in Class 2 and Class 3 $(H=0.75$ and 0.86 , respectively) and weight loss in Class 3 $(H=0.84)$. Broad-sense heritability was moderate for electrolyte leakage in Class $1(H=0.44)$ and moderate to low for percent $\mathrm{O}_{2}$ and $\mathrm{CO}_{2}$ in all fruit classes (range $H=0$ to 0.6 ).

\section{Discussion}

Variation for $\mathrm{O}_{2}$ and $\mathrm{CO}_{2}$ partial pressures, tissue weight loss, and electrolyte leakage was evident among fruit classes as well as among accessions within respective classes. Consistent with prior studies (Stommel et al., 2015), sweet bell and other large-fruited accessions had higher $\mathrm{O}_{2}$ partial pressures in comparison with jalapeno and serrano fruit types early in the storage period and declined with continued storage. For example, E20L.1012857 was represented in the current and former study and again maintained recommended $\mathrm{O}_{2}$ partial pressure between $3 \%$ and $5 \%$ and $\mathrm{CO}_{2}$ partial pressures less than $10 \%$ after extended storage.

Similarly, electrolyte leakage in large-fruited accessions that comprised Class 1 had reduced initial electrolyte 


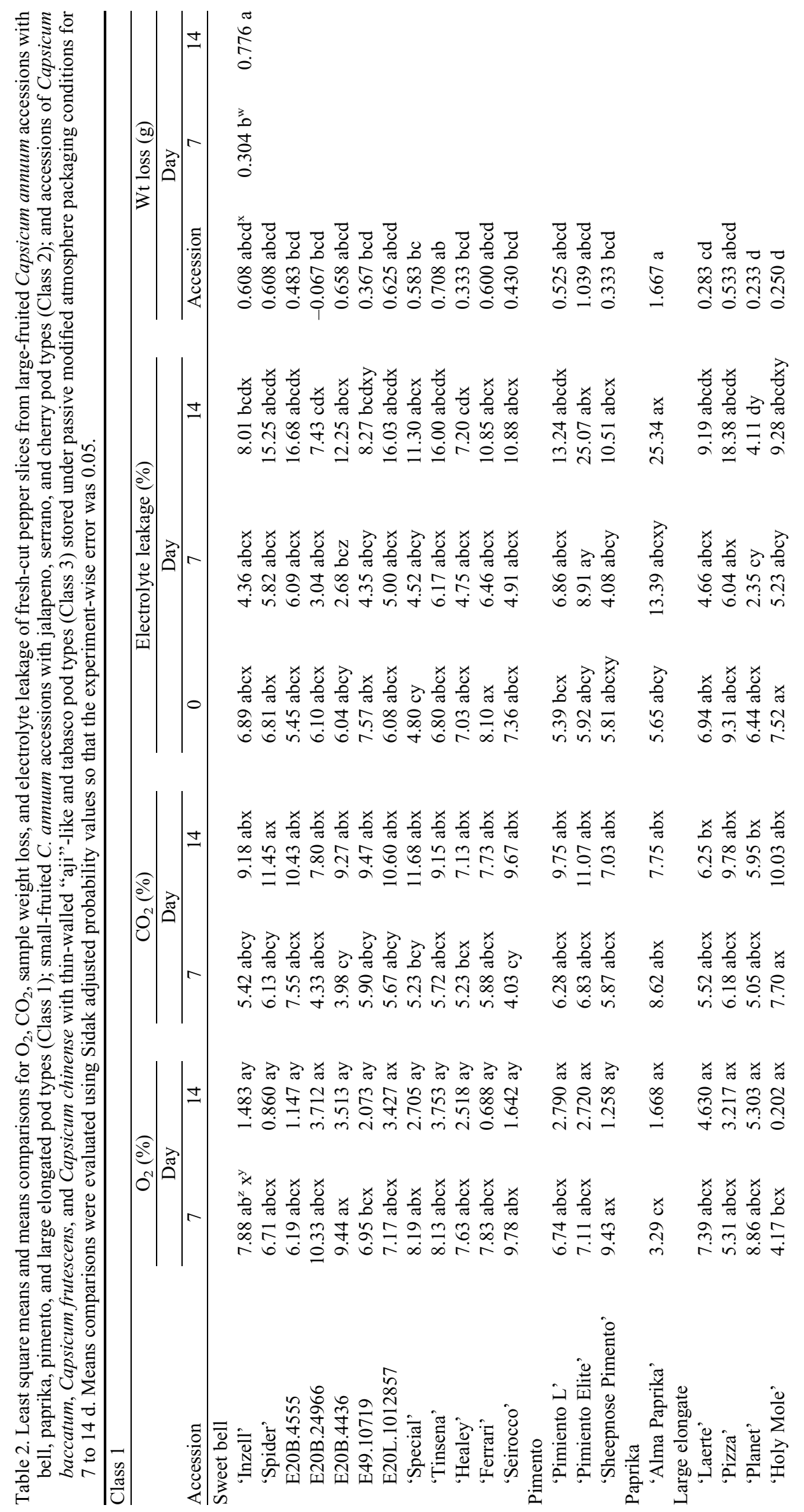




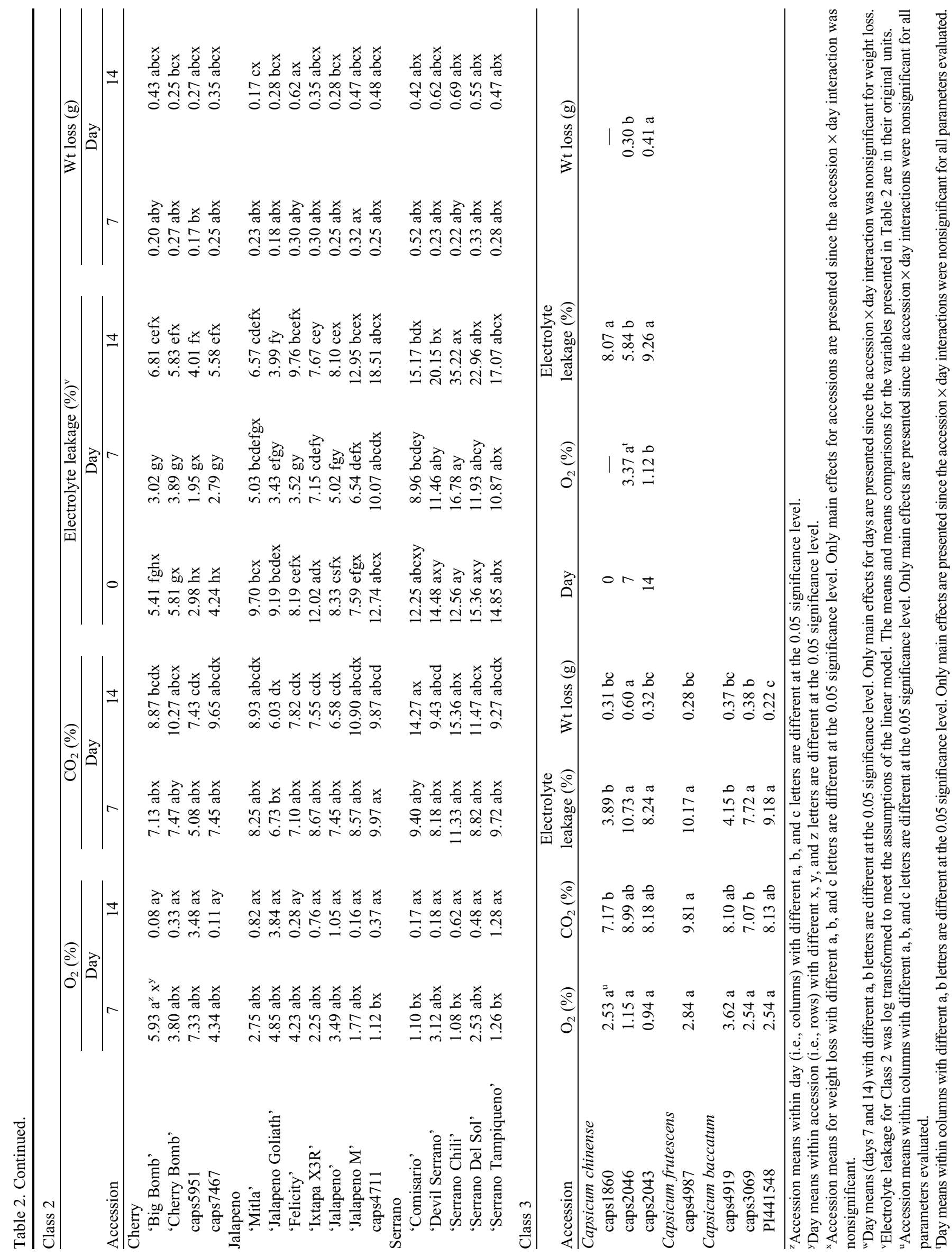


Table 3. Broad-sense heritability $(H)$ and the $95 \%$ confidence interval (CI) about $\mathrm{H}$ for $\mathrm{O}_{2}, \mathrm{CO}_{2}$, sample weight loss, and electrolyte leakage of fresh-cut pepper slices across large-fruited Capsicum annuиm accessions with bell, paprika, pimento, and large elongated pod types (Class 1); small-fruited $C$. annuum accessions with jalapeno, serrano, and cherry pod types (Class 2); and accessions of Capsicum baccatum, Capsicum frutescens, and Capsicum chinense with thin-walled "aji"-like and tabasco pod types (Class 3) stored under passive modified atmosphere packaging conditions for $14 \mathrm{~d}$.

\begin{tabular}{lcccc}
\hline Heritability estimate & $\mathrm{O}_{2}$ & $\mathrm{CO}_{2}$ & Wt loss & Electrolyte leakage \\
\hline Class 1 & & & & \\
H & 0.37 & 0 & 0.32 & 0.44 \\
Upper CI & 0.75 & 0.49 & 0.73 & 0.78 \\
$\quad$ Lower CI & -0.60 & -2.28 & -0.71 & -0.41 \\
Class 2 & & & & \\
H & 0.41 & 0.60 & 0.49 & 0.75 \\
Upper CI & 0.80 & 0.88 & 0.82 & 0.92 \\
Lower CI & -0.67 & -0.04 & -0.54 & 0.30 \\
Class 3 & & & & \\
H & 0 & 0.11 & 0.84 & 0.86 \\
Upper CI & 0.80 & 0.92 & 0.97 & 0.98 \\
Lower CI & -5.70 & -1.74 & 0.07 & 0.44 \\
\hline
\end{tabular}

leakage relative to jalapeno and serrano fruit types, but exhibited large increases in electrolyte leakage during storage relative to jalapeno and serrano fruit classes where these levels remained more constant. Intact pepper fruit that have greater wall thickness, higher dry matter and fruit firmness are generally expected to perform better during commercial harvest and postharvest handling (Gil and Tudela, 2012). We previously observed greater loss in firmness of fresh-cut large-fruited genotypes in comparison with jalapeno as well as serrano genotypes (Stommel et al., 2015). Higher initial electrolyte leakage found in some jalapeno and serrano accessions suggest that these fruit sustained more tissue injury during processing. Accessions represented across studies wherein electrolyte leakage remained relatively constant or declined over the storage period in the current and former study, included Class 1 accessions E20B.24966, E49.10719, 'Planet', and 'Holy Mole' and Class 2 accessions 'Mitla' and 'Ixtapa X3R'. Class 3 C. chinense, C. frutescens, and $C$. baccatum accessions behaved similarly to smallfruited $C$. annuum Class 2 accessions. As previously proposed, our observations on electrolyte leakage support occurrence of a membrane repair process in fresh-cut pepper where electrolyte leakage is stable or declines during extended storage (Kou et al., 2013; Stommel et al., 2015).

High levels of variance were evident for the fresh-cut attributes evaluated during storage. Despite this variability, trends observed during storage for $\mathrm{CO}_{2}$ and $\mathrm{O}_{2}$ partial pressures, tissue electrolyte leakage, and weight loss for the respective fruit classes were consistent with our prior observations. Some of the variability may be attributed to the difficulty of harvesting fruit at the same level of maturity and resultant physiological differences inherent in fruit of different maturity. Variation in maturity will influence softening and other ripening processes that continue in fresh-cut product after pepper fruit are harvested (Kader, 2002). Mimicking commercial harvest practices, harvest of green pepper fruit of different maturity at the same time is common despite efforts to harvest fruit with the same fruit color and firmness (Sanchez et al., 1993; Tadesse et al., 2002).

For most fresh-cut attributes, broad-sense heritability estimates were low to moderate. In general, the variation due to genotype $\times$ environment and error for $\mathrm{O}_{2}$ and $\mathrm{CO}_{2}$ partial pressures, tissue weight loss, and electrolyte leakage were comparable in Class 1 and Class 2. However, in Class 1, variation due to error for percent $\mathrm{O}_{2}$ was more than three times greater than that for genotype $\times$ environment, and error for percent $\mathrm{CO}_{2}$ in Class 2 was nearly 2 -fold greater than that for genotype $\times$ environment. For Class 3 , variation due to error was 3 - to 10-fold greater than that observed for genotype $\times$ environment. Within all fruit classes, the percentage of variation explained by error and genotype $\times$ environment was smallest for electrolyte leakage. Electrolyte leakage values from fresh-cut fruit reflects tissue damage sustained during cutting, whereas increases in electrolyte leakage during storage is indicative of cell disruption due to tissue breakdown that occurs as tissue ages and/or decays due to microbial growth. MA packaging is used to help prevent or slow tissue decay. Electrolyte leakage was the most robust quality measure among the attributes evaluated for fresh-cut pepper shelf life and may be considered a reliable selection criterion for breeding. Despite the general reliability of electrolyte leakage to assess tissue damage and trends observed over multiple studies for some pepper genotypes that exhibit acceptable fresh-cut shelf life, the poor precision of broadsense heritability estimates indicates that breeding for enhanced shelf life will be difficult. We previously identified good agreement between electrolyte leakage and sensory scores for overall fruit quality in fresh-cut sweet bell and other large-fruited $C$. annuum accessions (Stommel et al., 2015). Nonetheless, breeding for enhanced shelf life is daunting due to the large populations typically used in breeding and the laborious nature of analytical measures and/or need for trained panels for reliable sensory characterization.

Although few reports are available that document genetic diversity for fresh-cut quality among cultivated fruits and vegetables and their exotic relatives, recent studies highlight genetic diversity for fresh-cut attributes and, similar to our results, illustrate the challenges as well as the opportunities to breed for fresh-cut performance. In lettuce (Lactuca sativa) germplasm, Zhang et al. (2007) identified over 100 quantitative trait loci (QTL) across multiple linkage groups for lettuce shelf life that were environment specific and generally explained less than $30 \%$ of the observed variation. In different populations, Hayes et al. (2014) and Atkinson et al. (2013) also found multiple QTL that accounted for variation in fresh-cut lettuce shelf life, but identified a major QTL explaining $40 \%$ to $70 \%$ of the decay observed in cut lettuce (Hayes et al., 2014). Days of storage was the principal determinant of varied influence of this QTL.

Variation observed among Capsicum genotypes for electrolyte leakage and package atmospheric composition during storage of fresh-cut product highlights the opportunity to combine potentially different genetic mechanisms for improving fresh-cut shelf life. Populations developed from select parents will provide estimates of additive effects and utility of those genotypes in breeding for fresh-cut quality. 


\section{Literature Cited}

Allende, A., Y. Luo, J. McEvoy, F. Artés, and C. Wang. 2004. Microbial and changes in minimally processed baby spinach leaves stored under super atmospheric oxygen and modified atmosphere conditions. Postharvest Biol. Technol. 33:51-59.

Atkinson, L.D., L.K. McHale, M.J. Truco, H.W. Hilton, J. Lynn, J.W. Schut, R.W. Michelmore, P. Hand, and D.A.C. Pink. 2013. An intraspecific linkage map of lettuce (Lactuca sativa) and genetic analysis of postharvest discolouration traits. Theor. Appl. Genet. 126:2737-2752.

Barrett, D.M., J.C. Beaulieu, and R. Shewfelt. 2010. Color, flavor, texture, and nutritional quality of fresh-cut fruits and vegetables: Desirable levels, instrumental and sensory measurement, and the effects of processing. Crit. Rev. Food Sci. Nutr. 50:369-389.

Barth, M.M., H. Zhuang, and M.E. Saltveit. 2016. Fresh-cut vegetables, p. 624-641. In: K. Gross, C.Y. Wang, and M. Saltveit (eds.). The commercial storage of fruits, vegetables and florist and nursery stocks. U.S. Dept. Agr., Agr. Res. Serv., Agr. Hdbk No. 66. 31 Mar. 2016. <http://www.ars.usda.gov/is/np/CommercialStorage/ CommercialStorageIntro.htm $>$.

Cantwell, M.I. and T.V. Suslow. 2002. Postharvest handling systems: Fresh-cut fruits and vegetables, p. 445-464. In: A.A. Kader (ed.). Postharvest technology of horticultural crops. Univ. California, Davis, CA.

Conesa, A., F. Artés-Hernández, S. Geysen, B. Nicolaï, and F. Artés. 2007. High oxygen combined with high carbon dioxide improves microbial and sensory quality of fresh-cut peppers. Postharvest Biol. Technol. 43:230-237.

Gil, M.I. and J.A. Tudela. 2012. Postharvest requirements of peppers, p. 241-254. In: V.M. Russo (ed.). Peppers: Botany, production and uses. CABI, Cambridge, MA.

Gonzalez-Aguilar, G.A., J.F. Ayala-Zavala, S. Ruiz-Cruz, E. AcedoFelix, and M.E. Diaz-Cinco. 2004. Effect of temperature and modified atmosphere packaging on overall quality of fresh-cut bell peppers. Lebensm. Wiss. Technol. 37:817-826.

Hayes, R.J., C.H. Galeano, Y. Luo, R. Antonise, and I. Simko. 2014. Inheritance of decay of fresh-cut lettuce in a recombinant inbred line population from 'Salinas 88' × 'La Brillante'. J. Amer. Soc. Hort. Sci. 139:388-398.

Hayes, R.J. and Y.B. Luo. 2008. Genetic variation for shelf-life of salad-cut lettuce in modified atmosphere environments. J. Amer. Soc. Hort. Sci. 133:228-233.

Hong, J.H., D.J. Mills, C.B. Coffman, J.D. Anderson, M.J. Camp, and K.C. Gross. 2000. Tomato cultivation systems affect subsequent quality of fresh-cut fruit slices. J. Amer. Soc. Hort. Sci. 125:729-735. Howard, L.R. and C. Hernandez-Brenes. 1998. Antioxidant content and market quality of jalapeno pepper rings as affected by minimal processing and modified atmosphere packaging. J. Food Qual. 21:317-327.

James, J.B. and T. Ngarmask. 2010. Processing of fresh-cut tropical fruits and vegetables: A technical guide. FAO/RAP Publ., Bangkok, Thailand.
Kader, A.A. 2002. Quality parameters of fresh-cut fruit and vegetable products, p. 11-20. In: O. Lamikanara (ed.). Fresh-cut fruits and vegetables: Science, technology, and market. CRC Press, Boca Raton, FL.

Kim, J., Y. Luo, and K. Gross. 2004. Effect of package film on the quality of fresh-cut salad savoy. Postharvest Biol. Technol. 32:99-107.

Knapp, S.J., W.W. Stroup, and W.M. Ross. 1985. Exact confidence intervals for heritability on a progeny mean basis. Crop Sci. 25: 192-194.

Kou, L., Y. Luo, T. Yang, Z. Xiao, E. Turner, G. Lester, Q. Wang, and M.J. Camp. 2013. Postharvest biology, quality and shelf life of buckwheat microgreens. LWT Food Sci. Technol. 51:73-78.

Lamikanra, O. 2002. Preface, p. iv-v. In: O. Lamikanra (ed.). Fresh-cut fruits and vegetables: Science, technology and market. CRC Press, Boca Raton, FL.

Lopez-Galvez, G., R. El-Bassuoni, X. Nie, and I.N. Cantwell. 1997. Quality of red and green fresh-cut peppers stored in controlled atmosphere. Proc. 7th Intl. Controlled Atmosphere Res. Conf. 5:152-157.

Luo, Y., J.L. McEvoy, M.R. Wachtel, J.G. Kim, and Y. Huang. 2004. Package atmosphere affects postharvest biology and quality of freshcut cilantro leaves. HortScience 39:567-570.

Manolopoulou, H., G. Lambrinos, and G. Xanthopoulos. 2012. Active modified atmosphere packaging of fresh-cut bell peppers: Effect on quality indices. J. Food Res. 1:148-158.

Sanchez, V.M., F.J. Sundstrom, G.N. McClure, and N.S. Lang. 1993. Fruit maturity, storage and postharvest maturation treatments affect bell pepper (Capsicum annuum L.) seed quality. Sci. Hort. 54:191201.

Senesi, E., C. Prinzivalli, M. Sala, and M. Gennari. 2000. Physiochemical and microbiological changes in fresh-cut green bell peppers as affected by packaging and storage. Italian J. Food Sci. $12: 55-64$.

Stommel, J.R. and E. Albrecht. 2012. Genetics, p. 29-56. In: V.M. Russo (ed.). Peppers: Botany, production and uses. CABI, Cambridge, MA.

Stommel, J.R., M.J. Camp, Y. Luo, and A.M. Welten-Schoevaars. 2015. Genetic diversity provides opportunities for improvement of fresh-cut pepper quality. Plant Genet. Resour. Characterization Util. 14:112-120.

Tadesse, Y., E.W. Hewett, M.A. Nichols, and K.J. Fisher. 2002. Changes in physiochemical attributes of sweet pepper cv. Domino during fruit growth and development. Sci. Hort. 93:91-103.

University of Maryland. 2016. Peppers, p. F117-F131. In: A. Wyenandt (ed.). Mid-Atlantic commercial vegetable production recommendations. Univ. Maryland Ext. Bul. EB-137. 31 Mar. 2016. $<$ https://extension.umd.edu/mdvegetables/2016-commercial-vegetableproduction-recommendations-eb-137>.

Zhang, F.Z., C. Wagstaff, A.M. Rae, A.K. Sihota, C.W. Keevil, S.D. Rothwell, G.J.J. Clarkson, R.W. Michelmore, M.J. Truco, M.S. Dixon, and G. Taylor. 2007. QTLs for shelf life in lettuce co-locate with those for leaf biophysical properties but not with those for leaf developmental traits. J. Expt. Bot. 58:1433-1449. 